\title{
Home HealthCare Telemonitoring System for "Medication Titration" in the Treatment of Heart Failure: Architecture for an Interoperable Solution
}

\author{
Giovanny Barbosa-Casanova ${ }^{\psi}$, Juan C. Vanegas-Serna, Henry Andrade-Caicedo \\ Grupo de Dinámica Cardiovascular, Centro de Bioingeniería, Universidad Pontificia Bolivariana, \\ Medellín, Colombia
}

\begin{abstract}
Heart failure is a common condition in which the heart is unable to keep up with its workload. Therefore, oxygen and nutrients are no longer able to reach the cardiac cells, which worsens the situation of the whole heart. Treating an HF patient is challenging due to the co-morbidities and the numerous medications associated with the treatment. Medical dosage through titration of ACE inhibitors (ACEIs), Angiotensin receptor blockers (ARBs), beta-blockers and other drugs is a recommended procedure to reduce morbidity and mortality in HF patients. However, the procedure is performed under medical supervision at the hospital, lasting from one to four weeks. We propose a telemonitoring system to help clinicians to follow the patient through the Medication Titration procedure at home. We used commercial medical devices, certified on international communication standards to assure interoperability. Independently of the producer or brand, they can operate properly in the designed architecture. So far, we are able to connect two medical devices, blood pressure meter and weight scale, to a data hub. Then the data is rerouted to the cloud, where information is stored in a database. We use a commercial application to visualize the data through a friendly graphical interface.
\end{abstract}

Keywords — Health Informatics, Heart Failure, Interoperability, Personal Health Device, Telemedicine.

\section{Sistema de TElEMONitoreo DE SALUd EN CASA PARA "Titulación DE MEDICAMENTOS" EN EL TRATAMIENTO DE LA INSUFICIENCIA CARDÍACA: ARQUITECTURA PARA UNA SOLUCIÓN INTEROPERABLE}

\footnotetext{
Resumen - La insuficiencia cardíaca es una condición común en la que el corazón es incapaz de suministrar los volúmenes de sangre suficiente al organismo. Por lo tanto, el oxígeno y los nutrientes ya no son capaces de llegar a las células cardíacas, lo que empeora la situación de todo el corazón. Tratar a un paciente con IC es un desafío debido a las comorbilidades y los numerosos medicamentos asociados con el tratamiento. Dosis médica a través de la titulación de los inhibidores de la ECA(IECA), bloqueadores de los receptores de la angiotensina (ARA), beta bloqueadores y otros fármacos son procedimientos recomendados para reducir la morbilidad y la mortalidad en los pacientes con IC. Sin embargo, el procedimiento se realiza bajo supervisión médica en el hospital, con una duración de una a cuatro semanas. Proponemos un sistema de telemonitoreo para ayudar a los médicos a seguir al paciente a través del proceso de titulación de medicamentos en casa. Utilizamos dispositivos médicos comerciales,

\% Author's Mailing Address: geiner.barbosa@upb.edu.co

DOI: https://doi.org/10.24050/19099762.n21.2017.1171
} 
certificados con estándares internacionales de comunicación para asegurar la interoperabilidad. Independientemente del productor o la marca, estos pueden funcionar correctamente en la arquitectura diseñada. Hasta el momento, somos capaces de conectar dos dispositivos médicos, un medidor de presión arterial y una balanza, a un concentrador de datos. A continuación, los datos son redirigidos a la nube, donde la información se almacena en una base de datos. Utilizamos una aplicación comercial para visualizar los datos a través de una interfaz gráfica amigable.

Palabras clave - Informática de Salud, Insuficiencia Cardíaca, Interoperabilidad, Dispositivo de Salud Personal, Telemedicina.

\section{Sistema de telemonitoreo de SAÚde em CASA PARA "TitulaÇÃo de MEDICAMENTOS" NO TRATAMENTO DA INSUFICIÊNCIA CARDÍACA: ARQUITETURA PARA UMA SOLUĊ̃̃ INTEROPERABLE}

Resumo-A insuficiência cardíaca é uma condição comum na que o coração é incapaz de fornecer os volumes de sangue suficiente ao organismo. Portanto, o oxigénio e os nutrientes já não são capazes de chegar às células cardíacas, o que piora a situação de todo o coração. Tratar a um paciente com IC é um desafio devido às morbidades e os numerosos medicamentos associados com o tratamento. Dose médica através da titulação dos inibidores da ECA (IECA), bloqueadores dos receptores da angiotensina (ARA), beta bloqueadores e outros fármacos é um procedimento recomendado para reduzir a morbidade e a mortalidade nos pacientes com IC. No entanto, o procedimento realiza-se baixo supervisão médica no hospital, com uma duração de uma a quatro semanas. Propomos um sistema de telemonitoreo para ajudar aos médicos a seguir ao paciente através do processo de titulação de medicamentos em casa. Utilizamos dispositivos médicos comerciais, certificados em padrões internacionais de comunicação para assegurar a interoperabilidade. Independentemente do produtor ou a marca, eles podem funcionar corretamente na arquitetura desenhada. Até o momento, somos capazes de ligar dois dispositivos médicos, um medidor de pressão arterial e uma balança, a um concentrador de dados. A seguir, os dados são dirigidos à nuvem, onde a informação se aloja num banco de dados. Utilizamos um aplicativo comercial para visualizar os dados através de uma interface gráfica amigável.

Palavras-chave - Informática de Saúde, Insuficiência Cardíaca, Interoperabilidade, Dispositivo de Saúde Pessoal, Telemedicina.

\section{INTRODUCTION}

$\mathrm{H}$ eart failure (HF) is a condition in which the heart is unable to pump enough blood to accomplish the amount that the body needs [1]. According to the information presented by the American Heart Association (AHA), approximately 5.7 million of Americans have got HF [2]. In the case of Colombia, according to the Colombian Society of Cardiology and Cardiovascular Surgery, in 2012, approximately 1.1 million Colombians underwent this disease [3].

Due to the progressive nature of heart failure, its treatment often consists in applying combinations of drugs [1]. When a patient gets the hospital with symptoms that reflect instability, such as fatigue, edema, swelling of feet and ankles, shortness of breath, etc., usually, the common procedure consists in a treatment that aims to stabilize the patient by prescribing him a medication intravenously. The patient has to stay at the hospital during the whole process [4]. During the hospitalization period, the clinician will adjust the medication dosage. It will progressively increase until reaching the recommended dose, or up to the maximum dose tolerated by the patient [5]. This process can last from one to four weeks, depending on the patient condition and the medication. Once the clinician establishes de dose, the next step is to replace the intravenous medication by oral pills. This procedure is commonly known as "Medication Titration".

The high morbidity and mortality that HF causes have repercussions in the financial burden for health systems, mainly due to readmissions [6]. Home telemonitoring is presented as an alternative strategy, as it allows remote monitoring of patient symptoms and signs [6-9]. In the works of Raikhelkar and Raikhelkar [10] and Maric et al. [11], different techniques have been used telemedicine in cardiology studies. They have helped to reduce the rate of hospital admissions, morbidity, and mortality. These studies found that the main variables to follow are body weight, blood pressure, and heart rate, with positive results for its implementation. However, most of these systems use proprietary communication protocols, limiting the exchange of information to devices produced by the same manufacturer or brand. Furthermore, the lack of interoperability and standardization affects the integrity, security transfer and access to the reports generated by the system, preventing the successful implementation of telemedicine services [12-14].

International organizations are proposing and promoting the adoption of communication standards to allow interoperability between different devices and biomedical information systems used in health services. 
Some examples are The Personal Connected Health Alliance (PCHA), which develops design guidelines based on the family of standards ISO / IEEE 11073, the Integrating the Healthcare Enterprise (IHE) Patient Care Device PCD-01 Transaction, and the Health Level Seven International (HL7) Personal Health Monitoring Report (PHMR). PCHA also certifies products that meet the standard. This is a form to guarantee the interoperability between biomedical devices and the information systems at the hospitals, regardless of the manufacturer or device brand [15].

This paper describes the development of a telemonitoring system designed for HF patients during the procedure named "Medication Titration". The system utilizes an interoperable architecture that meets the international standards of communications described above.

\section{Materials And Methods}

We designed the telemonitoring system based on the Continua Design Guidelines (CDG), published by PCHA, the architecture looks for interoperability of every element of the system, from the biomedical device, passing through the gateway, the database, to the server application. Hence, we reviewed and selected medical devices that satisfied the standards suggested by CDG.

\section{A. Continua Design Guidelines Architecture}

The CDG define interfaces that ensure interoperability in the exchange of health information between medical devices, gateways, and information systems [16].

In the first interface called "Personal Health Devices", CDG proposes the use of the family of standards IEEE 11073. They define the data format and the exchange of information between medical devices and gateways. This family of standards fits in different communication protocols such as USB, Bluetooth, Bluetooth Low Energy (BLE), NFC, and ZigBee, which represents an advantage.

The Services Interface uses the IHE PCD-01 Transaction to exchange information between personal health gateways and medical or fitness services. This interface allows upload information, exchange messages, and authenticated persistent sessions, over a Wide Area Network (WAN). Also, the interoperability in this interface is achieved by constraining IHE specifications and HL7 standards.

The third and last interface defined by CDG is the Health Records Network (HRN), which uses HL7-based PMHR, for the electronic exchange of medical records. Transport of this reports is performed using IHE CrossEnterprise Document Sharing (XDS), which allow sharing medical documents between Hospital and Health Care Providers over WAN.

\section{B. Standards family IEEE 11073}

This set of standards was developed by the IEEE in order to allow interoperability between personal-use medical devices. Within them, the IEEE 11073:20601 standard defines a common framework to create an abstract model of personal health data, available in a transfer syntax independent of the communication protocol, that allows establishing logical connections between systems and provides the necessary services to perform communications tasks [17].

This standard classifies the medical devices into two types: Agents and Managers. The Agents are sensors that acquire medical information and transmit it. The Managers are devices that receive information from one or more Agents. Also, in this standard is presented a system model composed of three main parts: the Domain Information Model (DIM), the Service Model and the Communication Model. These models allow representing, to define and to communicate data.

DIM describes the Agent's data as a set of objects. Each object has one or more attributes. The attributes represent the measurement data that is transmitted to the Manager, as well as the elements that control the behavior and the state of the Agent.

The Service Model defines the conceptual mechanisms for the data exchange services. Besides, it provides the data access primitives that are transmitted between the Agent and the Manager. The message protocol used in this standard is defined in ASN.1.

The Communication Model supports the topology of one or more Agents that communicates with a Manager over a point-to-point connection. The system dynamic behavior, of each point-to-point connection, is defined by a state machine. Moreover, this model defines the entry, exit, and error conditions for each state. Also, in this model are included assumptions regarding the underlying communication layers' behavior.

\section{System Architecture}

The System architecture suggested by CDG is a chain where the information is transmitted from one system to another, following a sequence where the data from basic medical devices can reach the server using the Internet. Its importance lies in the communication standards that use on each level, bringing down the communication incompatibilities of different manufacturers and software products. For this project, we integrate three systems: 
medical devices, gateway, and web application. The system architecture is presented in Fig. 1.

For the communications between systems, we selected BLE and IHE Personal Care Device (PCD-01) for devicesgateway and gateway-server, respectively.

\section{Devices}

We searched devices that fit the communications protocol requirements for this project. We selected the A\&D Blood Pressure UA-651BLE and the A\&D Weight Scale UC352BLE, both with BLE communication. These devices follow the Bluetooth specifications for services and characteristics. They also can be used in a home environment and can be connected to an iPhone or Android mobile device.

The gateway system is a Health@home Linux Hub v2.0 from LNI. This system supports BLE transport and fulfills the CDG specifications for Bluetooth and USB communications with IEEE 11073 family standards. The data is translated internally to IHE PCD-01 (HL7 V2.6) for WAN transmission. To secure the information, it uses SAML authentication and HTTPS connection.

\section{E. Connection tests}

The first step was to ensure the devices were discovered by the gateway system. We used the gateway's local web application to search and pair the devices with the gateway. The second step was to take measurements from both devices and check the logs files to validate that the values were transmitted and uncorrupted. In the same logs files, we check for the translation of the data to an HL7 message.

For the HTTPS transmission, we used the demonstration system Health@home InSight provided by LNI. On this web application, we were able to see the data upload in real-time and historic mode. To check the security of the information we used the tcpdump Linux command and the program Wireshark. First, we searched the package for the SAML authentication, validating the XML negotiation. Then, we search the packages were the data of the medical devices were transmitted, verifying each body of the message was encrypted.

\section{F. Clinical protocol}

This system is designed to follow-up patients with heart failure during the "Medication Titration" process. To determine the technical and clinical feasibility of the system, a protocol is being developed, together with the clinical staff of Cardiovascular Unit of Hospital San Vicente Fundación. This protocol will define the frequency in which biomedical devices acquire the data, criteria for assessing the patient's condition, from data acquired, and duration of follow-up periods. The clinical team will check the platform daily and will give directions to the patient, in order to adjust the medication dosage.

\section{Results}

We implemented the system architecture proposed in Fig.1. The devices were tested in the laboratory, controlling the variables and the moments when measurements were taken. For the test, we used both UA-651BLE and UC352BLE. Ten measurements were taken with both devices and forty values were obtained, ten correspond to weight measured with the UC-352BLE and the others thirty correspond to systolic pressure, diastolic pressure, and pulse rate, measured with the UA-651BLE. We used gateway's logs files to search for the values reported from the devices. We contrasted the values reported on the gateway were, in fact, those reported locally by the devices.

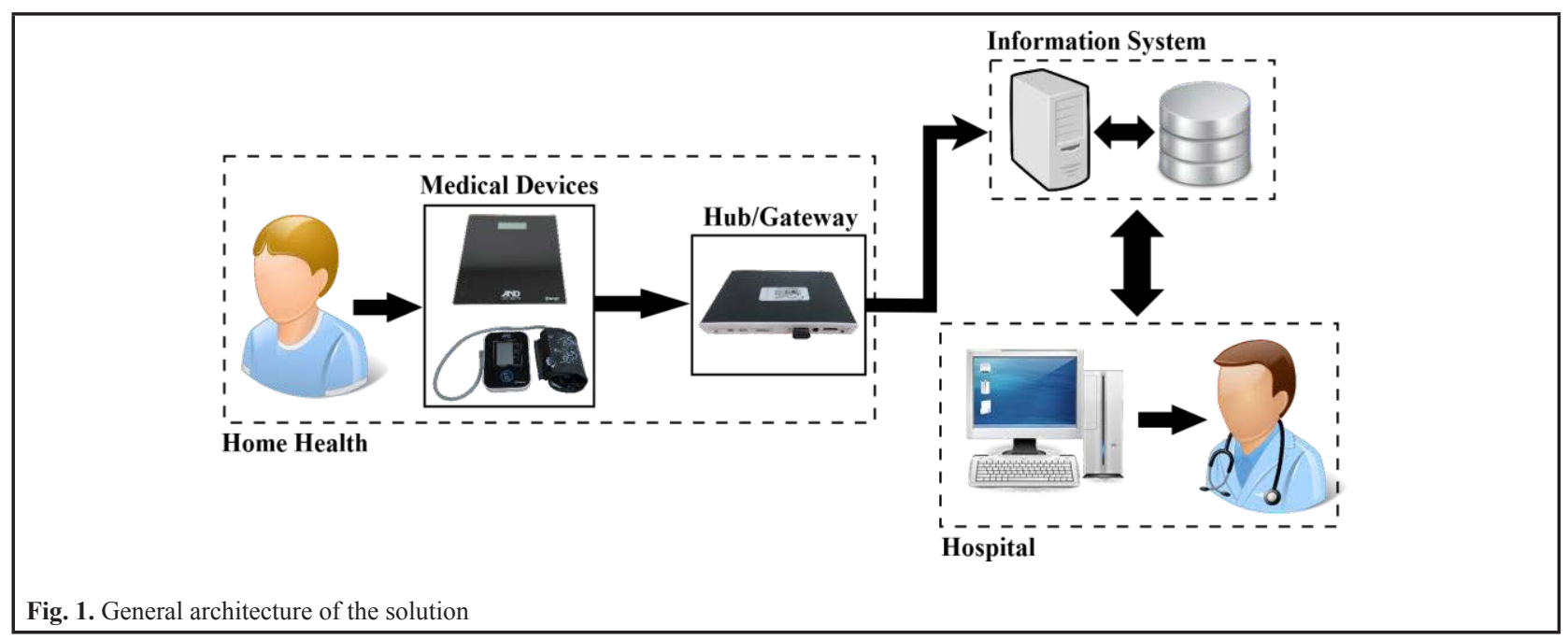


Table 1. Values taken by the biomedical devices during the test of the system

\begin{tabular}{ccccc}
\hline Measurement & $\begin{array}{c}\text { Weight } \\
(\mathrm{kg})\end{array}$ & $\begin{array}{c}\text { Systolic } \\
\text { pressure } \\
(\mathrm{mmHg})\end{array}$ & $\begin{array}{c}\text { Diastolic } \\
\text { pressure } \\
(\mathrm{mmHg})\end{array}$ & $\begin{array}{c}\text { Pulse Rate } \\
(\mathrm{bpm})\end{array}$ \\
\hline 1 & 64.9 & 125 & 91 & 64 \\
2 & 61.9 & 95 & 64 & 72 \\
3 & 70.2 & 111 & 70 & 80 \\
4 & 80.6 & 129 & 71 & 71 \\
5 & 68.4 & 105 & 74 & 74 \\
6 & 78.6 & 117 & 68 & 69 \\
7 & 66.3 & 101 & 73 & 52 \\
8 & 64.0 & 108 & 66 & 66 \\
9 & 42.3 & 81 & 51 & 77 \\
10 & 49.7 & 73 & 56 & 82 \\
\hline
\end{tabular}

The values correspond exactly between the device report and the gateway log file. For the web page, we used, again, the gateway's log files, but this time searching for the HL7 message. When the message was reported, we check the Health@home InSight application to corroborate if the information arrived correctly. We could verify that the measurements data was right and correspond to the one reported both in the device as the gateway.

We followed the data packages with tcpdump and reviewed them with Wireshark to validate the secure connection and transmission of the data. When we tried to read the body of each message sent to the server, we were unable to decipher the data due to the TLS V1.2 secure layer of the communication, verifying the encryption of the data from end-to-end.

\section{Discussion}

The tests performed in the laboratory shows that the developed system is able to acquire information from the patient and transmit it securely and correctly to a server. Likewise, the variables acquired by this system along with the monitoring of fluid intake and diuresis, allow performed a follow-up of the condition of the patient with HF, during the Medication Titration process. Also, the interoperable architecture presented by this system allow its adaptation to different scenarios, as well as the addition of new devices, regardless of the manufacturer or brand. However, is necessary perform tests in a domiciliary environment to determine the viability and usability of the system in the monitoring of patients in this kind of environments.

\section{Conclusion}

This paper presents a remote telemonitoring system of physiological variables, designed for heart failure patients, during the procedure of medication titration, which consists of commercial devices that meet international standards of interoperability.

The architecture of the system presented in this paper is based on the standards contained in the CDG. The system consists of three parts: medical devices, gateway, and web application. The exchange of information between medical devices and the gateway was performed through BLE, while the exchange of information between the gateway and the web application was performed using IHE PCD-01. The main advantage of this system is that is totally interoperable, furthermore, it allows the easy integration of new devices, as long as they meet with the standards contained in the CDG. These characteristics show that the system is able for the monitoring and control of diseases different to heart failure.

The results of the tests performed, show that the system is to able of to acquire information from the patient, encrypting it and transmit it to a reference center, where it can be stored, displayed and analyzed.

\section{ACKNOWLEDGMENT}

The authors would like to thank to Professor Iván Mora, Engineer Mauricio Aristizábal, and students Aysha Villamizar and Camilo González for their help handling the devices, and the medical staff of Hospital San Vicente Fundación: Cardiovascular Unit, for the advice provided during the develop of this research.

\section{REFERENCES}

[1]. V. Gol Vallés and C. Barroso Peréz, "Farmacología de la insuficiencia cardíaca," Farm. Hosp., vol. 20, no. 3, pp. 149-156, 1996.

[2]. D. Mozaffarian, E. J. Benjamin, A. S. Go, D. K. Arnett, M. J. Blaha, M. Cushman, S. R. Das, S. de Ferranti, J.-P. Després, H. J. Fullerton, V. J. Howard, M. D. Huffman, C. R. Isasi, M. C. Jiménez, S. E. Judd, B. M. Kissela, J. H. Lichtman, L. D. Lisabeth, S. Liu, R. H. Mackey, D. J. Magid, D. K. McGuire, E. R. Mohler, C. S. Moy, P. Muntner, M. E. Mussolino, K. Nasir, R. W. Neumar, G. Nichol, L. Palaniappan, D. K. Pandey, M. J. Reeves, C. J. Rodriguez, W. Rosamond, P. D. Sorlie, J. Stein, A. Towfighi, T. N. Turan, S. S. Virani, D. Woo, R. W. Yeh, and M. B. Turner, "Heart Disease and Stroke Statistics-2016 Update," Dec. 2015.

[3]. C. Jaramillo, E. Gómez, E. Hernández, C. Saldarriaga, N. Flórez, R. Buitrago, C. Dueñas, M. Jaramillo, D. Isaza, L. E. Echeverría, M. Poveda, J. L. Accini, G. González, Á. García, S. Navarrete, M. J. Rodríguez, J. E. Gómez, C. Arias, D. Molano, F. Mendoza, A. Rivera, F. Rivera, N. Roa, Á. Quintero, F. Rosas, B. Rolong, C. 
Plata, J. M. Sarmiento, L. F. Aponte, A. Figueredo, J. Ramírez, G. Sarmiento, D. Sánchez, and A. Torres, "Definición, etiología, clasificación y epidemiología," in Consenso Colombiano para el Diagnóstico y Tratamiento de la Insuficiencia Cardiaca Cronica, Sociedad C., Bogotá D.C.: Sociedad Colombiana de Cardiología y Cirugía Cardiovascular, 2014, pp. 7-9.

[4]. Organización Mundial de la Salud, "Guía de la buena prescripción - Manual práctico," Organización Mundial de la Salud, 1998. [Online]. Available: http://apps.who. $\mathrm{int} /$ medicinedocs/es/d/Jh2991s/7.1.5.2.html. [Accessed: 26-Apr-2016].

[5]. National Hearth Foundation of Australia, "Titrating Medications in Heart Failure," HEART Online, 2016. [Online]. Available: http://www.heartonline.org.au/articles/medications/ titratingmedications-in-heart-failure\#general-approach-totitration. [Accessed: 26-Apr-2016].

[6]. J. T. Sørensen, P. Clemmensen, and M. Sejersten, "Telecardiología: pasado, presente y futuro," Rev. Española Cardiol., vol. 66, no. 3, pp. 212-218, 2013.

[7]. K. Dickstein, A. Cohen-Solal, G. Filippatos, J. J. V. McMurray, P. Ponikowski, P. A. Poole-Wilson, A. Strömberg, D. J. van Veldhuisen, D. Atar, A. W. Hoes, A. Keren, A. Mebazaa, M. Nieminen, S. G. Priori, K. Swedberg, A. Vahanian, J. Camm, R. De Caterina, V. Dean, K. Dickstein, G. Filippatos, C. FunckBrentano, I. Hellemans, S. D. Kristensen, K. McGregor, U. Sechtem, S. Silber, M. Tendera, P. Widimsky, J. L. Zamorano, M. Tendera, A. Auricchio, J. Bax, M. Böhm, U. Corrà, P. della Bella, P. M. Elliott, F. Follath, M. Gheorghiade, Y. Hasin, A. Hernborg, T. Jaarsma, M. Komajda, R. Kornowski, M. Piepoli, B. Prendergast, L. Tavazzi, J.-L. Vachiery, F. W. A. Verheugt, J. L. Zamorano, and F. Zannad, "ESC Guidelines for the diagnosis and treatment of acute and chronic heart failure 2008," Eur. J. Heart Fail., vol. 10, no. 10, pp. 933-989, Oct. 2008.

[8]. C. E. Grau, J. C. Colet, and J. M. V. Rotellar, "Aplicaciones de la telemedicina en el seguimiento de insuficiencia cardíaca: experiencia en una unidad integral," FMC - Form. Médica Contin. en Atención Primaria, vol. 22, no. 4, pp. 188-195, 2015.

[9]. R. A. Clark, S. C. Inglis, F. A. McAlister, J. G. F. Cleland, and S. Stewart, "Telemonitoring or structured telephone support programmes for patients with chronic heart failure: systematic review and meta-analysis," BMJ, vol. 334, no. 7600, pp. 942-942, May 2007.

[10]. J. Raikhelkar and J. K. Raikhelkar, "The Impact of Telemedicine in Cardiac Critical Care," Crit. Care Clin., vol. 31, no. 2, pp. 305317, Apr. 2015.

[11]. B. Maric, A. Kaan, A. Ignaszewski, and S. A. Lear, "A systematic review of telemonitoring technologies in heart failure," Eur. J. Heart Fail., vol. 11, no. 5, pp. 506-517, May 2009.

[12]. Y. B. Choi, J. S. Krause, Hyewon Seo, K. E. Capitan, and Kyusuk Chung, "Telemedicine in the USA: standardization through information management and technical applications," IEEE Commun. Mag., vol. 44, no. 4, pp. 41-48, Apr. 2006.

[13]. S. Jimenez-Fernandez, P. de Toledo, and F. del Pozo, "Usability and Interoperability in Wireless Sensor Networks for Patient Telemonitoring in Chronic Disease Management," IEEE Trans. Biomed. Eng., vol. 60, no. 12, pp. 3331-3339, Dec. 2013.

[14]. B. B. Traore, B. Kamsu-Foguem, and F. Tangara, "Integrating MDA and SOA for improving telemedicine services," Telemat. Informatics, vol. 33, no. 3, pp. 733-741, Aug. 2016.
[15]. Personal Connected Health Alliance, "ABOUT PCHA," The Personal Connected Health Alliance, 2017. [Online]. Available: http://www.pchalliance.org/about-pcha. [Accessed: 15-Dec2016].

[16]. Personal Connected Health Alliance, "Fundamentals of Data Exchange,” 2015. [Online]. Available: https://cw.continuaalliance. org/document/d1/13473.

[17]. IEEE, 11073-20601-2014 - IEEE Health informatics--Personal health device communication - Part 20601: Application profileOptimized Exchange Protocol. 2014. 